\title{
Role of non-nitric oxide non- prostaglandin endothelium-derived relaxing factor(s) in bradykinin vasodilation
}

\section{A.C. Resende, \\ G. Ballejo and \\ M.C.O. Salgado}

\author{
Departamento de Farmacologia, Faculdade de Medicina de Ribeirão Preto, \\ Universidade de São Paulo, Ribeirão Preto, SP, Brasil
}

\section{Correspondence \\ M.C.O. Salgado \\ Departamento de Farmacologia \\ FMRP, USP \\ Av. Bandeirantes, 3900 \\ 14049-900 Ribeirão Preto, SP \\ Brasil \\ Fax: 55-16-633-2301 \\ E-mail: mcdosalg@ fmrp.usp.br}

Presented at the II International Symposium on Vasoactive Peptides, O uro Preto, MG, Brasil,

October 6-8, 1997.

Research supported by FAPESP and CNPq.

Received April 8, 1998

Accepted April 24, 1998

\section{Abstract}

The most conspicuous effect of bradykinin following its administration into the systemic circulation is a transient hypotension due to vasodilation. In the present study most of the available evidence regarding the mechanisms involved in bradykinin-induced arterial vasodilation is reviewed. It has become firmly established that in most species vasodilation in response to bradykinin is mediated by the release of endothelial relaxing factors following the activation of $\mathrm{B}_{2^{-}}$ receptors. Although in some cases the action of bradykinin is entirely mediated by the endothelial release of nitric oxide (NO) and/or prostacyclin $\left(\mathrm{PGI}_{2}\right)$, a large amount of evidence has been accumulated during the last 10 years indicating that a non-NO/PGI ${ }_{2}$ factor accounts for bradykinin-induced vasodilation in a wide variety of perfused vascular beds and isolated small arteries from several species including humans. Since the effect of the non-NO/PGI 2 endothelium-derived relaxing factor is practically abolished by disrupting the $\mathrm{K}^{+}$ electrochemical gradient together with the fact that bradykinin causes endothelium-dependent hyperpolarization of vascular smooth muscle cells, the action of such factor has been attributed to the opening of $\mathrm{K}^{+}$ channels in these cells. The pharmacological characteristics of these channels are not uniform among the different blood vessels in which they have been examined. Although there is some evidence indicating a role for $\mathrm{K}_{\mathrm{Ca}}$ or $\mathrm{K}_{\mathrm{V}}$ channels, our findings in the mesenteric bed together with other reports indicate that the $\mathrm{K}^{+}$channels involved do not correspond exactly to any of those already described. In addition, the chemical identity of such hyperpolarizing factor is still a matter of controversy. The postulated main contenders are epoxyeicosatrienoic acids or endocannabinoid agonists for the $\mathrm{CB}_{1}$-receptors. Based on the available reports and on data from our laboratory in the rat mesenteric bed, we conclude that the $\mathrm{NO} / \mathrm{PGI}_{2}$-independent endothelium-dependent vasodilation induced by $\mathrm{BK}$ is unlikely to involve a cytochrome P450 arachidonic acid metabolite or an endocannabinoid agonist.
Key words

- Prostaglandin

- Bradykinin

- Nitric oxide

- Cytochrome P450

- Potassium channels

- Endothelium-dependent vasodilation 
Fifty years ago Professor M.O. da Rocha e Silva described a factor released from plasma globulins by trypsin or snake venom that caused hypotension in rabbits and cats (1). The purification and later synthesis of the factor now known as bradykinin gave a great impetus to the characterization of the full range of its pharmacological effects (2). Among these, the most conspicuous is the hypotensive effect when bradykinin is administered into the systemic circulation in all species studied. This hypotensive effect results mainly from a decrease in vascular resistance most probably by arteriolar dilation in several organs including heart, kidney, gut, liver and skeletal muscle $(3,4)$.

The mechanism responsible for the arteriolar dilation induced by bradykinin remains to be fully elucidated and it may vary in different arteries of the same species or according to the size of the artery in the same organ or even the same artery in different species. Progress in the understanding of such a mechanism was hampered by the lack of consistent responses of isolated vessels to bradykinin and by the apparent paradoxical observation in most helically cut vascular strips of a vasoconstrictor or absent response

Figure 1 - Hypotensive effect of bradykinin $(0.5$ and $1.0 \mu \mathrm{g})$ before and after intravenous administration of the NO synthase inhibitor L-NMMA $(50 \mathrm{mg} / \mathrm{kg})$ in conscious normal male rats. The upper panel shows a representative tracing of directly recorded arterial blood pressure. The lower panel shows the mean \pm SEM values $(\mathrm{N}=4)$ of the hypotensive effect expressed as percentage of pre-bradykin injection mean blood pressure.

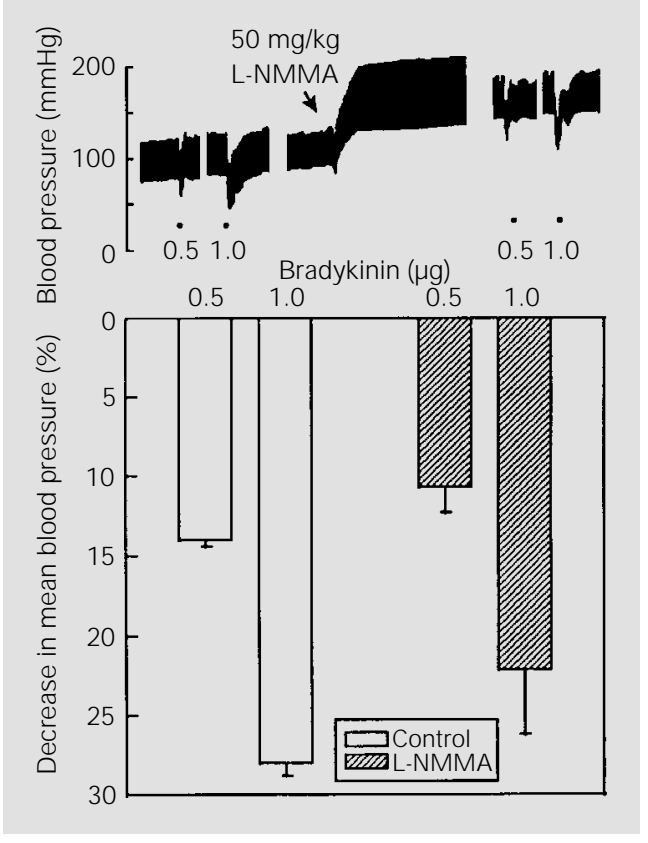

in pre-1980 studies (2). It was only after Professor R. Furchgott (5) demonstrated the role of endothelial cells in mediating the acetylcholine-vasodilator effect, which was immediately extended to the action of bradykinin by Altura and Chand (6), that the functional integrity of the endothelium in isolated blood vessel preparations was considered to be crucial to obtain consistent responses. Furthermore, these observations established the notion that endothelial cells produce and release relaxant factors (EDRF) in response to a wide range of vasodilator agents (7). The identification of nitric oxide (NO), or a related compound derived from L-arginine, as the main EDRF together with the observation that bradykinin was capable of inducing the release of $\mathrm{NO}$ from endothelial cells in culture (8-10) led to the proposal that the vasodilator and hypotensive effects of bradykinin are mediated by the release of NO by endothelial cells. Although initial observations using $\mathrm{L}$-arginine analogues that inhibit NO synthase showed that these compounds attenuated the hypotensive effect of bradykinin in normal rats (11), results from our laboratory showed that the magnitude of the hypotensive effect of bradykinin in conscious rat was unaltered by $\mathrm{N}^{\mathrm{G}}$-nitromonomethyl $\mathrm{L}$-arginine administration, even at doses that raised mean arterial pressure by $50 \mathrm{mmHg}$ (Figure 1). Similar findings were reported by other groups using other inhibitors of NO synthase (12-14). These observations led us to reinvestigate the role of $\mathrm{NO}$ in the endothelium-dependent relaxation induced by bradykinin in isolated resistance vessels of the rat employing the isolated and perfused mesenteric bed (15). This vascular bed was selected because it has been consistently reported that bradykinin infusion either in vitro or in vivo into the mesenteric circulation causes vasodilatation in rats (1619), rabbits (20), dogs (21), cats (22), and humans (23). Firstly, we observed that in phenylephrine-preconstricted vessels bradykinin causes a dose-dependent relaxation at 
the lower doses and a biphasic response, relaxation followed by constriction, at the higher doses. The vasodilator effect was abolished by endothelial removal, while the vasoconstrictor one remained unaltered (15). These findings indicate that the vasodilator effect is indeed endothelium-dependent, whereas the vasoconstrictor effect most likely results from a direct action on smooth muscle and involves prostaglandin synthesis since indomethacin, an inhibitor of cyclooxygenase, abolished it and prolonged the vasodilator effect (Figure 2). In addition, we observed that the magnitude of the vasodilator effect was not affected by indomethacin or $\mathrm{N}^{\mathrm{G}}$-nitro L-arginine, an inhibitor of $\mathrm{NO}$ synthase, but was abolished by the $\mathrm{B}_{2}$-receptor antagonist HOE-140, indicating that it depends on the activation of kinin $\mathrm{B}_{2}$-receptors, but does not involve NO or prostaglandin synthesis.

$\mathrm{B}_{2}$-receptor activation in cultured endothelial cells has been shown to augment the release of both NO and prostacyclin (24). In addition, earlier reports have shown that cyclooxygenase inhibitors impaired the vasodilator action of bradykinin in the rat skeletal muscle circulation as well as in the isolated rabbit heart $(25,26)$ and in rabbit and cat superior mesenteric arteries (27). On the other hand, bradykinin-induced vasodilation of the mesenteric bed in vivo in anesthetized rats has been shown to be attenuated by $\mathrm{N}^{\mathrm{G}}$ nitro L-arginine (19). The results of our experiments (Figure 3) are in apparent conflict with these reports but are entirely consistent with more recent studies showing that in guinea pig and rat isolated heart, in rat isolated kidney, and in the intact dog and human coronary circulation bradykinin-induced vasodilation is partially or totally resistant to NO or prostaglandin synthesis inhibitors (2832). Furthermore, bradykinin-induced relaxation independent of the release of prostanoid and NO has been described in porcine, bovine and human coronary arteries (33-35) and human small omental arteries (36).

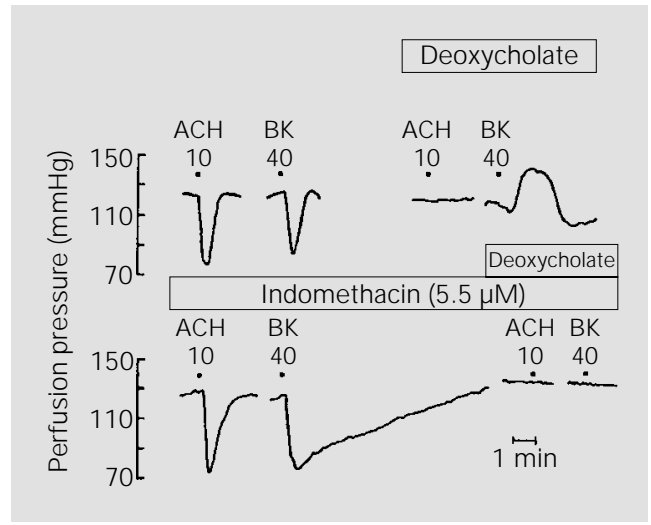

In rings of pig, canine and human coronary as well as human gastroepiploic arteries, bradykinin elicited transitory hyperpolarization of smooth muscle cells which was endothelium dependent (37-40). Although NO and prostacyclin are capable of causing smooth muscle hyperpolarization in some vessels (41-44), most of the endothelium-dependent smooth muscle hyperpolarization induced by vasodilator agents is unaffected by NO synthase or cyclooxygenase inhibitors (45). Thus, the existence of a still chemically unidentified endothelium-derived hyperpolarizing factor (EDHF) has been postulated. The hyperpolarization of vascular smooth muscle cells induced by EDHF has been attributed to an increase in smooth muscle membrane $\mathrm{K}^{+}$conductance since it is impaired by disruption of the $\mathrm{K}^{+}$electro-

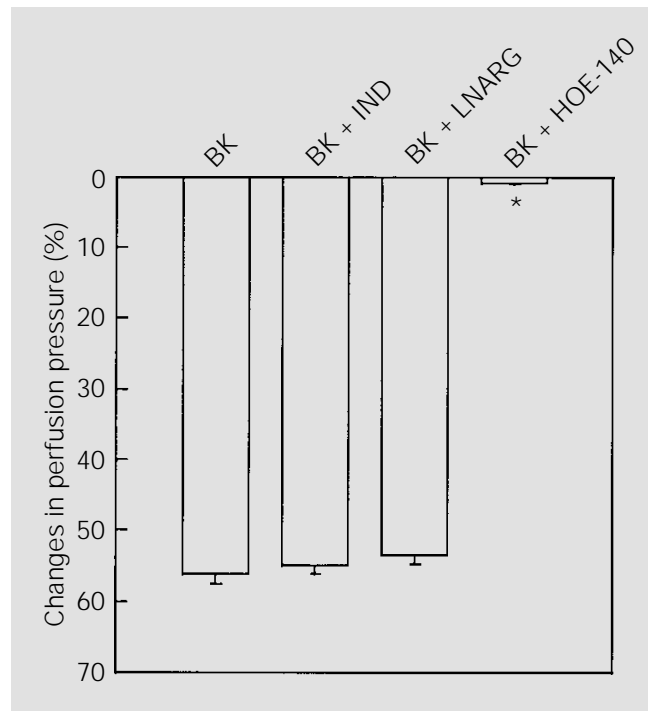

Figure 2 - Typical recordings show examples of the effect of endothelium removal with sodium deoxycholate on the response to acetylcholine $(\mathrm{ACH}$; $10 \mathrm{ng}$ ) and bradykinin (BK; 40 ng) in preconstricted rat isolated mesenteric arterial bed perfused with Krebs' solution (top panel) or Krebs' solution containing the cyclooxygenase inhibitor indomethacin (bottom panel).

Figure 3 - Vasodilator effect of bradykinin (BK; $40 \mathrm{ng}$ ) in the absence or in the presence of the cyclooxygenase inhibitor indomethacin (BK + IND; $5.5 \mu \mathrm{M}$ ), or the NO synthase inhibitor NGnitro-L-arginine (BK + LNARG; $200 \mu \mathrm{M}$ ), or the $B_{2}-$ kinin receptor antagonist HOE-140 (BK + HOE-140; $250 \mathrm{nM})$. Values (mean \pm SEM) represent the percent decrease in mesenteric perfusion pressure ( $\mathrm{N}=4-6$ ). $* P<0.05$ vs BK (Student t-test). 
Figure 4 - Vasodilator effect of bradykinin (BK; $40 \mathrm{ng}$ ) in the absence or in the presence of the potassium channel blockers glibenclamide (BK + GLIB; $3 \mu \mathrm{M})$, apamin (BK + APAM; $1 \mu \mathrm{M})$, 4 aminopyridine (BK + 4-AP; 1 $\mathrm{mM})$, tetraethylammonium (BK +TEA; $3 \mathrm{mM}$ ), iberiotoxin (BK + IBTX, $100 \mathrm{nM})$ or high $\mathrm{K}^{+}(\mathrm{BK}+$ $\mathrm{K}^{+} ; 47 \mathrm{mM}$ ). Values (mean \pm SEM ) represent the percent decrease in mesenteric perfusion pressure $(\mathrm{N}=4-6)$. $* \mathrm{P}<0.05$ vs BK (Student t-test).

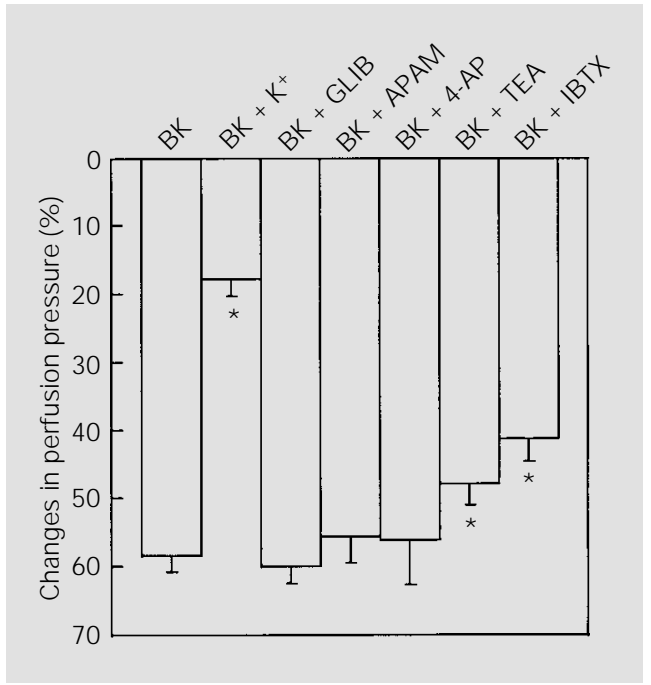

chemical gradient (46). Consequently, we determined the effect of disruption of the $\mathrm{K}^{+}$ gradient on bradykinin-induced vasodilation in the rat mesenteric arteries. Increasing extracellular $\mathrm{K}^{+}$concentration to $40 \mathrm{mM}$ reduced the magnitude of the vasodilatory response by $80 \%$ (Figure 4), suggesting that in this vascular bed the NO- and prostaglandinindependent vasodilator effect of bradykinin results from an increase in $\mathrm{K}^{+}$conductance. The potassium channels involved in these responses could be located either in smooth muscle or in endothelial cells and their identity remains to be fully defined (47). The magnitude of $\mathrm{NO} /$ prostanoid-independent vasodilation induced by acetylcholine in the rabbit abdominal aorta and carotid artery (48) or by bradykinin in rat isolated and perfused heart and kidney $(49,50)$ has been shown to be reduced by charybdotoxin (an inhibitor of large conductance $\mathrm{BK}_{\mathrm{Ca}}$ and also some $\mathrm{K}_{\mathrm{V}}$ channels). On the other hand, apamin (an inhibitor of small conductance $\mathrm{K}_{\mathrm{Ca}}$ channels) has been shown to inhibit NOindependent vasodilation induced by bradykinin in porcine coronary arteries (51). Glibenclamide (an inhibitor of $\mathrm{K}_{\mathrm{ATP}}$ channels) has been shown to inhibit NO- and prostaglandin-independent relaxation of rabbit abdominal aorta (48). Other studies, however, have reported conflicting observations (47) suggesting that several pharmacologically distinct $\mathrm{K}^{+}$channels are involved in the $\mathrm{NO} /$ prostanoid-independent endothelium-dependent vascular smooth muscle hyperpolarization and/or relaxation. In order to characterize the $\mathrm{K}^{+}$channel underlying this response we proceeded to test the effect of selective $\mathrm{K}^{+}$channel blockers such as glibenclamide, apamin, 4-aminopyridine, and iberiotoxin, as well as the rather nonselective $\mathrm{K}^{+}$channel blocker tetraethylammonium. At the concentrations employed, which have been shown to be fully effective in other studies, only iberiotoxin and tetraethylammonium were able to reduce, and only partially, the magnitude of bradykinin-induced vasodilation (Figure 4). These data suggest that part of the vasodilation depends on the activation of $\mathrm{BK}_{\mathrm{Ca}}$ channels; the remaining vasodilation most probably reflects the activity of other $\mathrm{K}^{+}$channels with a unique pharmacology. Since $\mathrm{K}^{+}$channels are oligomeric structures, we cannot discard the possibility that a single $\mathrm{K}^{+}$channel containing an iberiotoxin-sensitive subunit underlies the vasodilation induced by bradykinin. Indeed, $\mathrm{K}^{+}$channels mediating the hyperpolarization induced by acetylcholine-released EDHF in the rat hepatic artery as well as in the guinea pig carotid artery exhibit pharmacological properties distinct from those of the already described $\mathrm{K}^{+}$channels $(44,52,53)$.

Regardless of the precise nature of the $\mathrm{K}^{+}$ channel involved in endothelium-dependent hyperpolarization, it has been postulated that endothelium-dependent relaxation resistant to NO synthase and cyclooxygenase inhibitors might be mediated by epoxyeicosatrienoic acids (EET), metabolites of arachidonic acid formed by the action of cytochrome P450 enzymes, or by endogenous cannabinoid agonists such as anandamide $(47,51$, 54). Therefore, we determined the effect of two rather nonselective inhibitors of cytochrome P450 monooxygenases, SKF525A (proadifen) and 7-ethoxyresorufin, as well as the alleged selective EET synthesis inhib- 
itor clotrimazole. In addition, we also determined the effect of the cannabinoid $\mathrm{CB}_{1^{-}}$ receptor antagonist SR141716A (55) on bradykinin-induced vasodilation of the rat mesenteric bed (Figure 5). As can be observed in the figure, clotrimazole was the only agent capable of reducing the magnitude of bradykinin-induced vasodilation. This effect of clotrimazole is unlikely to have resulted from an inhibition of cytochrome P450 monooxygenases, since the other two inhibitors of these enzymes failed to influence bradykinin response. Although we cannot rule out that a P450 enzyme insensitive to SKF525A or ethoxyresorufin is involved, it is worth noting that in these experiments the two inhibitors were able to reduce the magnitude of acetylcholine-induced vasodilation (15). This interpretation is entirely consistent with recent reports showing that the endothelium-dependent hyperpolarization of the rat mesenteric arteries is not mediated by cytochrome P450 metabolites of arachidonic acid $(56,57)$. Since clotrimazole has been shown to block $\mathrm{K}^{+}$channels in different cells, including vascular smooth muscle cells (58), it is likely that the effect of clotrimazole resulted from a blockade of potassium channels.

In conclusion, the reviewed evidence suggests that bradykinin is capable of inducing endothelial cells to release at least three relaxant mediators: prostacyclin, $\mathrm{NO}$ and EDHF. The contribution of each of these

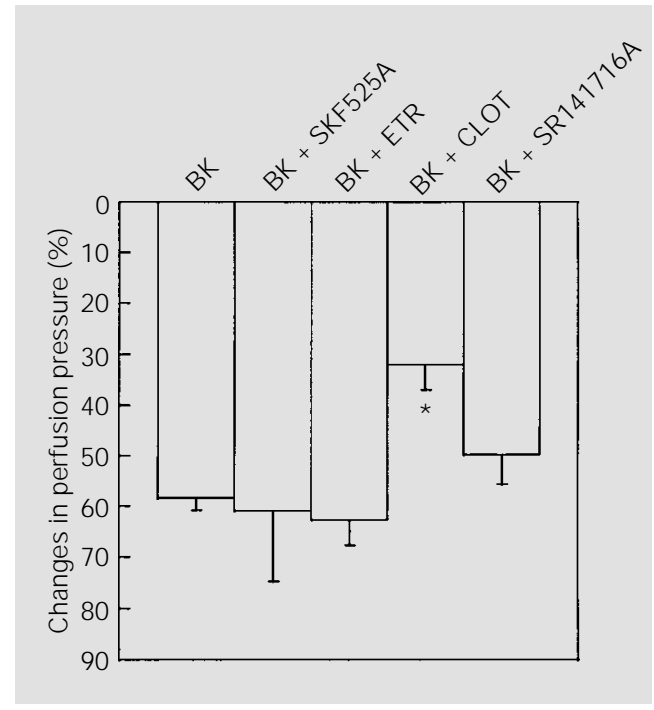

Figure 5 - Vasodilator effect of bradykinin (BK; $40 \mathrm{ng}$ ) in the absence or in the presence of the cytochrome P450 enzymes SKF525A (BK + SKF525A; 5 $\mu M)$, ethoxyresorufin (BK +ETR; $5 \mu \mathrm{M})$, clotrimazole (BK + CLOT; $5 \mu \mathrm{M})$, or the $\mathrm{CB}_{1}$-cannabinoid receptor antagonist SR141716A $(B K+$ SR141716A; $1 \mu \mathrm{M})$. Values (mean \pm SEM) represent the percent decrease in mesenteric perfusion pressure $(\mathrm{N}=4-6)$. $* \mathrm{P}<0.05$ vs BK (Student t-test). mediators to the relaxant effect of bradykinin is determined by the species, blood vessel and possibly by the contractile agent employed. Our observations suggest that NO does not appear to be the major EDRF mediating the mesenteric vasodilation and the hypotensive effect of bradykinin in normal rats. In addition, these findings also suggest that the potassium channel involved in the vasodilator effect exhibits pharmacological properties different from the currently described voltage- and calcium-dependent potassium channels. Finally, the EDHF involved in the rat mesenteric bed vasodilation induced by BK appears not to be a cytochrome P450 metabolite or endocannabinoid agonist for the $\mathrm{CB}_{1}$ receptor.

\section{References}

1. Rocha e Silva M, Beraldo WT \& Rosenfeld G (1949). Bradykinin, a hypotensive and smooth muscle stimulating factor released from plasma globulin by snake venoms and by trypsin. American J ournal of Physiology, 156: 261-273.

2. Regoli D \& Barabe J (1980). Pharmacology of bradykinin and related kinins. Pharmacological Reviews, 32: 1-46.

3. Antonio A \& Rocha e Silva M (1962). Coronary vasodilation produced by bradykinin on isolated mammalian heart. Circula- tion Research, 11: 910-915.

4. Haddy FJ, Emerson J r TE, Scott J B \& Daugherty J r RM (1970). The effect of the kinins on the cardiovascular system. In: Erdös EG (Editor), Bradykinin, Kallidin and Kallikrein Handbook of Experimental Pharmacology, 25: 362-384.

5. Furchgott RF \& Zawadzki J V (1980). The obligatory role of endothelial cells in the relaxation of arterial smooth muscle by acetylcholine. Nature, 288: 373-376.

6. Altura BM \& Chand N (1981). Bradykinin- induced relaxation of renal and pulmonary arteries is dependent upon intact endothelial cell. British J ournal of Pharmacology, 74: 10-11.

7. Furchgott RF \& Vanhoutte PM (1989). Endothelium-derived relaxing and contracting factors. FASEB J ournal, 3: 2007-2018.

8. Palmer RMJ , Ferrige AG \& Moncada $S$ (1987). Nitric oxide release accounts for the biological activity of endothelium-derived relaxing factor. Nature, 327: 524 526. 
9. Palmer RMJ , Ashton DS \& Moncada S (1988). Vascular endothelial cells synthetize nitric oxide from $\mathrm{L}$-arginine. $\mathrm{Na}$ ture, 333: 664-666.

10. Myers PR, Minor J rRL, Guerra J rR, Bates J N \& Harrison DG (1990). Vasorelaxant properties of the endothelium-derived relaxing factor more closely resemble Snitrocysteine than nitric oxide. Nature, 345: 161-163.

11. Whittle BR, Lopez-Belmonte J \& Rees DD (1989). Modulation of the vasodepressor actions of acetylcholine, bradykinin, substance $P$ and endothelin in the rat by a specific inhibitor of nitric oxide formation. British J ournal of Pharmacology, 98: 646652.

12. Gardiner SM, Compton AM, Kemp PA \& Bennet T (1990). Regional and cardiac haemodynamic responses to glyceryl trinitrate, acetylcholine, bradykinin and endothelin-1 in conscious rats: effects of $\mathrm{NG}^{\mathrm{G}}$-nitro-L-arginine methyl ester. British J ournal of Pharmacology, 101: 632-639.

13. O'Shaughnessy KM, Newman CM \& Warren J B (1992). Inhibition in the rat of nitric oxide synthesis in vivo does not attenuate the hypotensive action of acetylcholine, ATP or bradykinin. Experimental Physiology, 77: 285-292.

14. Bjfrnstad-Østensen A \& Berger T (1994). The role of nitric oxide, adrenergic activation and kinin degradation in blood pressure homeostasis following an acute kinin-induced hypotension. British J ournal of Pharmacology, 113: 1567-1573.

15. Resende AC, Ballejo G, Leite R \& Salgado MCO (1997). Role of NO-independent mechanisms in bradykinin-induced vasodilation in the rat mesenteric bed. Pharmacology Reviews and Communications, 9: 269-278.

16. Dienemann H, Wood J M, Kraetz J , Stalder R \& Hobauer G (1983). Haemodynamic effects of bradykinin in rats. Advances in Experimental Medicine and Biology, 156: 651-657.

17. Wang Y-X, Gavras I, Lammek B, Bresnahan M \& Gavras H (1991). Effects of bradykinin and prostaglandin inhibition on systemic and regional hemodynamics in conscious normotensive rats. J ournal of Hypertension, 9: 805-812.

18. Salgado MCO, Caldo H \& Rodrigues MCG (1992). Effect of bradykinin on isolated mesenteric arteries of the rat. Hypertension, 19 (Suppl II): 251-254.

19. Berguer $R$, Hottenstein $O D$, Palen $T E$, Stewart J M \& J acobson ED (1993). Bradykinin-induced mesenteric vasodilation is mediated by $\mathrm{B}_{2}$-subtype receptor and ni- tric oxide. American J ournal of Physiology, 264: G492-G496.

20. Bennet BM, Moffat J Á, Armstrong PW \& Marks GS (1983). Investigation of the role of prostaglandins in nitroglycerin-induced relaxation of isolated rabbit blood vessels. Canadian J ournal of Physiology and Pharmacology, 61: 554-560.

21. Fiksen-Olsen MJ, Britton SL, Houck PC \& Romero JC (1983). Effect of SQ-20881 and captopril on mesenteric, renal, and iliac vasculatures. American J oumal of Physiology, 244: H313-H319.

22. Lippton HL \& Kadowitz PJ (1981). Inhibition of vasoconstrictor and vasodilator responses by Pgel in the intestinal vascular bed of the cat. Prostaglandin and Medicine, 7: 537-552.

23. Erikson $U$, Fagerberg $S$, Krause $U$ \& Olding L (1970). Angiographic studies in Crohn's disease and ulcerative colitis. American J ournal of Roentgenology Radium Therapy and Nuclear Medicine, 110: 385-392.

24. D'Orléans-J uste $P$, de Nucci $G \&$ Vane J R (1989). Kinins act on $B_{1}$ and $B_{2}$ receptor to release conjointly endothelium-derived relaxing factor and prostacyclin from bovine aortic endothelial cells. British J ournal of Pharmacology, 96: 920-926.

25. Messina EJ , Weiner R \& Kaley G (1975). Inhibition of bradykinin vasodilation and potentiation of norepinephrine and angiotensin vasoconstriction by inhibitors of prostaglandin synthesis in skeletal muscle of the rat. Circulation Research, 37: 430437.

26. Needleman $P$, Key SL, Denny $S E$, Isakson PC \& Marshall GR (1975). Mechanism and modification of bradykinin-induced coronary vasodilation. Proceedings of the $\mathrm{Na}$ tional Academy of Sciences, USA, 72: 2060-2063.

27. Cherry PD, Furchgott RF, Zawadski JV \& J othianandan D (1982). Role of endothelial cells in relaxation of isolated arteries by bradykinin. Proceedings of the National Academy of Sciences, USA, 79: 21062110.

28. Vials $A$ \& Burnstock $G$ (1992). Effect of nitric oxide synthase inhibitors, L-NG_ nitroarginine and $\mathrm{L}-\mathrm{NG}$-nitroarginine meth$\mathrm{yl}$ ester, on responses to vasodilators of the guinea-pig coronary vasculature. British J ournal of Pharmacology, 107: 604609.

29. Baydoun AR \& Woodward B (1991). Effect of bradykinin in the rat isolated perfused heart: role of kinin receptors and endothelium-derived relaxing factor. British J ournal of Pharmacology, 103: 1829-
1833.

30. Bauersachs J, Hecker $M \&$ \& Busse $R$ (1994). Display of the characteristics of endothelium-derived hyperpolarizing factor by a cytochrome P450-derived arachidonic metabolite in the coronary microcirculation. British J ournal of Pharmacology, 113: 1548-1553.

31. Fulton D, McGiff J C \& Quilley J (1992). Contribution of $\mathrm{NO}$ and cytochrome P450 to the vasodilator effect of bradykinin in the rat kidney. British J ournal of Pharmacology, 107: 722-725.

32. Sudhir K, MacGregor J S, Amidon TM, Gupta M, Yock PG \& Chatterjee K (1994). Differential contribution of nitric oxide to regulation of vascular tone in coronary conductance and resistance arteries: intravascular ultrasound studies. American Heart J ournal, 127: 858-865.

33. Cowan CL \& Cohen RA (1991). Two mechanisms mediate relaxation by bradykinin of pig coronary artery: NO-dependent and -independent responses. American J ournal of Physiology, 261: H830H835.

34. Tschudi M, Richard V, Buhler FR \& Lusher TF (1991). Importance of endothelium-derived nitric oxide in porcine coronary resistance arteries. American J ournal of Physiology, 260: H13-H2O.

35. Kemp BK \& Cocks TM (1997). Evidence that mechanisms dependent and independent of nitric oxide mediate endothelium-dependent relaxation to bradykinin in human small resistance-like coronary arteries. British J oumal of Pharmacology, 120: 757-762.

36. Ohlmann P, Martinez MC, Schneider F, Stoclet J C \& Andriantsitohaina R (1997). Characterization of endothelium-derived relaxing factors released by bradykinin in human resistance arteries. British J ournal of Pharmacology, 121: 657-664.

37. Pacicca $C$, von der Weid PY \& Bény J L (1992). Effect of nitro-L-arginine on endothelium-dependent hyperpolarizations and relaxations of pig coronary arteries. J ournal of Physiology, 457: 247-256.

38. Mombouli JV, Illiano S, Nagao T, ScottBurden T \& Vanhoutte PM (1992). The potentiation of endothelium-dependent relaxations to bradykinin by angiotensin I converting enzyme inhibitors in the canine coronary artery involves both endothelium-derived relaxing and hyperpolarizing factors. Circulation Research, 71: 137143.

39. Nakashima M, Mombouli J V, Taylor AA \& Vanhoutte PM (1993). Endothelium-dependent hyperpolarization caused by 
bradykinin in human coronary arteries. J ournal of Clinical Investigation, 92: 28672871.

40. Urakami-Harasawa L, Shimokawa $H$, Nakashima M, Egashira K \& Takeshita A (1997). Importance of endothelium-derived hyperpolarizing factor in human arteries. J ournal of Clinical Investigation, 100: 2793-2799.

41. Tare $M$, Parkington HC, Coleman HA, Neild TO \& Dusting GJ (1990). Hyperpolarization and relaxation of arterial smooth muscle caused by nitric oxide derived from the endothelium. Nature, 346: 6971.

42. Garland CJ \& McPherson GA (1992). Evidence that nitric oxide does not mediate the hyperpolarization and relaxation to acetylcholine in the rat small mesenteric artery. British J ournal of Pharmacology, 105: 429-465.

43. Cohen RA, Plane F, Najibi S, Huk I, Malinski T \& Garland CJ (1997). Nitric oxide is the mediator of both endotheliumdependent relaxation and hyperpolarization of the rabbit carotid artery. Proceedings of the National Academy of Sciences, USA, 94: 4193-4198.

44. Corriu C, Félétou M, Canety E \& Vanhoutte PM (1996). Endothelium-derived factors and hyperpolarization of the carotid artery of the guinea-pig. British J ournal of Pharmacology, 119: 959-964.

45. Mombuli J V \& Vanhoutte PM (1997). Endothelium-derived hyperpolarizing factor(s): updating the unknown. Trends in Pharmacological Sciences, 18: 252-256.
46. Garland CJ, Plane F, Kemp BK \& Cocks TM (1995). Endothelium-dependent hyperpolarization: a role in the control of vascular tone. Trends in Pharmacological Sciences, 16: 23-30.

47. Quilley J, Fulton D \& McGiff J C (1997). Hyperpolarizing factors. Biochemical Pharmacology, 54: 1059-1070.

48. Cowan $\mathrm{CL}$, Palacino J J , Najibi $\mathrm{S} \&$ Cohen RA (1993). Potassium channel-mediated relaxation to acetylcholine in rabbit arteries. J ournal of Pharmacology and Experimental Therapeutics, 266: 1482-1489.

49. Fulton K, McGiff J C \& Quilley J (1994). Role of $\mathrm{K}^{+}$channels in the vasodilator response to bradykinin in the rat heart. British J ournal of Pharmacology, 113: 954958.

50. Rapacon M, Mieyal P, McGiff J C, Fulton D \& Quilley J (1996). NO-independent renal vasodilation to bradykinin: role of $\mathrm{K}^{+}$ channels. British J ournal of Pharmacology, 118: 1504-1508.

51. Hecker M, Bara AT, Bauersachs J \& Busse R (1994). Characterization of endothelium-derived hyperpolarizing factor as a cytochrome P450-derived arachidonic acid metabolite in mammals. J ournal of Physiology, 481: 407-414.

52. Zygmunt PM, Edwards G, Weston $A H$, Larsson B \& Högestätt ED (1997). Involvement of voltage-dependent potassium channels in the EDHF-mediated relaxation of rat hepatic artery. British J ournal of Pharmacology, 121: 141-149.

53. Chataigneau $T$, Félétou $M$, Thollon $C$, Velleneuve N, Vilaine J -P, Duhault J \&
Vanhoutte PM (1998). Cannabinoid CB 1 receptor and endothelium-dependent hyperpolarization in guinea-pig carotid rat mesenteric and porcine coronary arteries. British J oumal of Pharmacology, 123: 968974.

54. Randall MD \& Kendall DA (1998). Endocannabinoids: a new class of vasoactive substances. Trends in Pharmacological Sciences, 19: 55-58.

55. Rinaldi-Carmona $M$, Barth $F$, Héaulme $M$, Shire D, Calandra B, Congy C, Martinez S, Maruani J, Néliat G, Caput D, Ferrara P, Soubrié P, Brelière J C \& Le Fur G (1994). SR141716A, a potent and selective antagonist of the brain cannabinoid receptor. FEBS Letters, 350: 240-244.

56. Fukao M, Hattori Y, Kanno M, Sakuma I \& Kitabatake A (1997). Evidence against a role of cytochrome P450-derived arachidonic acid metabolites in endotheliumdependent hyperpolarization by acetylcholine in rat isolated mesenteric artery. British J oumal of Pharmacology, 120: 439446.

57. Vanheel B \& Van de Voorde J (1997). Evidence against the involvement of cytochrome P450 metabolites in endothelium-dependent hyperpolarization of the rat main mesenteric artery. J ournal of Physiology, 501: 331-341.

58. Zygmunt PM, Edwards G, Weston AH, Davis SC \& Högestätt ED (1996). Effect of cytochrome P450 inhibitors on EDHF-mediated relaxation in the rat hepatic artery. British J ournal of Pharmacology, 118: 1147-1152. 